\begin{tabular}{|l|l|l|}
\hline \multicolumn{2}{|c|}{ PublisherInfo } \\
\hline \hline PublisherName & $:$ & BioMed Central \\
\hline \hline PublisherLocation & $:$ & London \\
\hline \hline PublisherImprintName & $:$ & BioMed Central \\
\hline \hline
\end{tabular}

\title{
Perfidious proteobacterium
}

\begin{tabular}{|l|l|l||}
\hline \multicolumn{2}{|c|}{ ArticleInfo } \\
\hline \hline ArticleID & $:$ & 4896 \\
\hline \hline ArticleDOI & $:$ & $10.1186 /$ gb-spotlight-20031212-02 \\
\hline \hline ArticleCitationID & $:$ & spotlight-20031212-02 \\
\hline \hline ArticleSequenceNumber & $:$ & 248 \\
\hline \hline ArticleCategory & $:$ & Research news \\
\hline ArticleFirstPage & $:$ & 1 \\
\hline \hline ArticleLastPage & $:$ & 1 \\
\hline \hline & & RegistrationDate : 2003-12-12 \\
ArticleHistory & $:$ & OnlineDate \\
\hline \hline ArticleCopyright & $:$ & BioMed Central Ltd2003-12-12 \\
\hline \hline ArticleGrants & $:$ & \\
\hline \hline ArticleContext & $:$ & 130594411 \\
\hline \hline
\end{tabular}




\section{Cathy Holding}

Email: cholding@hgmp.mrc.ac.uk

The $\delta$-Proteobacterium Geobacter sulfurreducens is of considerable ecological importance due to its wide range of biotechnologically exploitable bioremediation capabilities: the organism is involved in carbon cycling, can precipitate soluble metals, and has the ability to generate electricity. In the December 12 Science, Barbara Methé and colleagues at The Institute for Genomic Research report a thorough analysis of the genomic sequence of this bacterium that reveals capabilities including the capacity for aerobic and carbon metabolism, chemotaxis, and motility that were hitherto unexpected (Science 2003, 302:1967-1969).

Methé et al. examined the 3.8-Mb G. sulfurreducens genome, containing 3466 predicted coding sequences, by phylogenetic profiling - comparison of gene sequences across species - and observed that the bioremedial capabilities of this organism are not due simply to the presence of a unique set of genes, but also to expansion of gene family members. They identified a citrate synthase gene previously found only in eukaryotes, enzymes in the acetyl co-enzyme A pathway involved in acetate and carbon $\left(\mathrm{C}_{1}\right)$ metabolism, and enzymes involved in energy capture. Of 111 coding sequences for c-type cytochrome motifs, 73 contain two or more heme groups. Gene sequences enabling survival during oxic episodes were identified, as was the ability to aerobically metabolize complex carbons, and in addition, the presence of multiple regulatory molecules indicated the need to adapt to rapidly changing conditions.

"The G. sulfurreducens genome has not only provided remarkable new insights into its unique metabolic capabilities and strategies for environmental survival, but has also made us rethink Geobacter physiology. This species may be neither immobile nor a strict anaerobe. It also possesses extraordinary electron transport capability and sensory potential, highlighted by the unprecedented collection of newly reported c-type cytochromes, the range and depth of which will best be appreciated in the light of comparative studies," the authors conclude.

\section{References}

1. Electricity production by Geobacter sulfurreducens attached to electrodes

2. Science, [http://www.sciencemag.org/]

3. The Institute for Genomic Research, [http://www.tigr.org/] 